\title{
Assessment of Sowing Window of Rice-Pulse Cropping System According to the Length of Growing Period and Different Climatic Parameter Analysis in Dhenkanal District of Odisha, India
}

\author{
D. Jena*, A. K. B. Mohapatra, B. S. Rath and A. Baliarsingh \\ Department of Agricultural Meteorology, College of Agriculture, \\ Odisha University of Agriculture and Technology, Bhubaneswar (Odisha) 751003, India \\ *Corresponding author
}

\section{A B S T R A C T}

\begin{abstract}
The present study was undertaken to determine the sowing window of kharif rice and rabi pulses in different blocks of Dhenkanal district based on the rainfall probability, temperature and length of growing period. The sowing window of kharif rice in Dhenkanal district was found between 23-24 Standard meteorological week (SMW) except Kankadahad, when the conditional probabilities of wet followed by wet (Pww) was $>50 \%$. In medium land condition, sowing of pulses (green gram and black gram) is done in 40 SMW in Kankadahad, 41 SMW in Bhuban, Dhenkanal sadar, Hindol, Kamakhyanagar, Parajang and 42 SMW in Odapada by zero till method. In low land condition of Dhenkanal, rabi pulses can be sown in between 44-45 SMW in Dhenkanal sadar and Hindol by zero till method after rice harvest and in between 40-41 SMW in Kanakadahad, 41-42 SMW in Bhuban, Dhenkanalsadar, Kamakhyanagar and 42-43 SMW in Odapada and Parajang with the utilization of residual soil moisture by paira method i.e. 15-20 days before the harvest of rice. The average weekly minimum temperature is $20-24{ }^{\circ} \mathrm{C}$ and chances of occurrence of wet weeks are more than $30 \%$ at $20 \mathrm{~mm}$ threshold limit of rainfall which is optimum for seeding and germination of pulses in that sowing week.
\end{abstract}

\section{Keywords}

LGP, rabi pulses, Rice-fallow, SMW

Article Info

Accepted:

15 April 2020

Available Online:

10 May 2020

\section{Introduction}

Timely planting under adequate soil moisture is the key to realize higher productivity in rice and pulses. Timely planted crop takes care of residual soil moisture efficiently, and robust root growth of the crop could resist soil moisture stresses that might come in the latter crop growth stages. Besides the constraints observed inherent to rice fallows, growing of profitable (second) crop cultivation, suitable strategies for alteration in sowing windows of both kharif and rabi crop could be a boon for conserving natural resources and higher productivity realization (Kar et al., 2004; Praharaj et al., 2018). The time of rabi sowing in rice-fallows at a particular place depends on the time of harvesting of rice, 
which in turn depends upon either duration of the rice variety or time of transplanting (Singh et al., 2016). So, there is need for the criterion to be used in identifying the onset dates for the ongoing season to enable the farmers to better plan their seasonal cropping activities (Bussmann et al., 2016).

\section{Materials and Methods}

The study was conducted in Dhenkanal district of Odisha located between $85^{\circ} 58^{\prime} \mathrm{E}$ to $86^{\circ} 20^{\prime} \mathrm{E}$ longitude and $20^{\circ} 29^{\prime} \mathrm{N}$ to $21^{\circ} 11^{\prime} \mathrm{N}$ latitudes under mid central table land zone of Odisha covering eight number of blocks namely Bhuban, Dhenkanal sadar, Gondia, Kamakhyanagar, Hindol, Kanakadaahad, Parajang and Odapada (Fig. 1).

All the weather data like morning and evening relative humidity $\left(\mathrm{RH}_{1}, \mathrm{RH}_{2}\right)$, bright sunshine hours (BSH), wind speed (WS) and evaporation (E) has been collected from the Department of Agricultural Meteorology, OUAT, and Bhubaneswar for the period 1995-2017 (23 years). Block wise rainfall data of Dhenkanal has been obtained from SRC site of Govt. of Odisha for the same period.

\section{Rainfall characterization}

Mean value of annual, seasonal, monthly and weekly rain fall and rainy day and also normal daily rainfall were found out by analyzing rainfall block wise over a period of 23 years. Block wise daily rainfall data were collected from Special Relief Commissioner (SRC), Odisha. In this study the 'Weather Cock' software was used for weather data analysis.

\section{Spatial and temporal variability of rainfall}

Mean annual, seasonal, monthly, weekly and daily rainfall and rainy day and variability of rainfall were found out by analyzing block wise daily rainfall data over a period of 23 years using Weather cock. "Rainy Day.exe" module was used to analyze the rainfall data. Standard deviation (SD) and Co-efficient of variance $(\mathrm{CV})$ were calculated by using statistical equation.

\section{Interpolation techniques}

The inverse distance weighting interpolator assumes that each input point has a local influence that diminishes with distance. It weights the points closer to the processing cell greater than those further away. A specified number of points or all points within a specified radius can be used to determine the output value of each location. Use of this method assumes the variable being mapped decreases in influence with distance from its sampled location. This interpolation technique is used for the mapping of seasonal rainfall distribution of Dhenkanal district by using "Arc GIS" software.

\section{Markov chain probability model for dry and wet spell analysis}

Simple criterion related to sequential phenomenon like dry and wet spell was used for analyzing rainfall data to obtain specific information needed for crop planning and for carrying out agricultural operations. In this study, weekly rainfall values have been computed from daily data series and were used for estimation of initial, conditional probabilities and consecutive dry and wet spell analysis based on 'Markov chain probability model'.

In this method, $20 \mathrm{~mm}$ or more rainfall in a week is considered as wet week otherwise dry as the previous researchers (Dash and Senapati, 1992; Joseph et al., 2017), who used $20 \mathrm{~mm}$ as the threshold value. Initial, conditional probabilities and consecutive dry 
and wet spell analysis for 52 standard meteorological weeks (SMW) are made by using equations from 1-10.

\section{Initial probability}

$\mathrm{P}(\mathrm{D})=\mathrm{F}(\mathrm{D}) / \mathrm{N}$

$\mathrm{P}(\mathrm{W})=\mathrm{F}(\mathrm{W}) / \mathrm{N}$

Where,

$\mathrm{P}(\mathrm{D})=$ probability of the week being dry

$\mathrm{F}(\mathrm{D})=$ frequency of dry weeks

$\mathrm{P}(\mathrm{W})=$ probability of the week being wet

$\mathrm{F}(\mathrm{W})=$ frequency of wet weeks

$\mathrm{N}=$ total number of years of data being used

\section{Conditional probabilities}

$\mathrm{P}(\mathrm{DD})=\mathrm{F}(\mathrm{DD}) / \mathrm{F}(\mathrm{D})$

$\mathrm{P}(\mathrm{WW})=\mathrm{F}(\mathrm{WW}) / \mathrm{F}(\mathrm{W})$

$\mathrm{P}(\mathrm{WD})=1-\mathrm{P}(\mathrm{DD})$

$\mathrm{P}(\mathrm{DW})=1-\mathrm{P}(\mathrm{WW})$

Where,

$\mathrm{P}(\mathrm{DD})=$ probability of a week being dry preceded by another dry week

$\mathrm{F}(\mathrm{DD})=$ frequency of dry week preceded by another dry week

$\mathrm{P}(\mathrm{WW})=$ probability of a week being wet preceded by another wet week

$\mathrm{F}(\mathrm{WW})=$ frequency of a wet week preceded by another wet week

$\mathrm{P}(\mathrm{WD})=$ probability of a wet week preceded by a dry week

$\mathrm{P}(\mathrm{DW})=$ probability of a dry week preceded by a wet week

\section{Consecutive dry and wet week probabilities}

$\mathrm{P}(2 \mathrm{D})=\mathrm{P}(\mathrm{DW} 1) \times \mathrm{P}(\mathrm{DDW} 2)$

$\mathrm{P}(3 \mathrm{D})=(\mathrm{DW} 1) \times \mathrm{P}(\mathrm{DDW} 2) \times \mathrm{P}(\mathrm{DDW} 3)(\mathrm{Eq} .8)$

$\mathrm{P}(2 \mathrm{~W})=\mathrm{P}(\mathrm{WW} 1) \times \mathrm{P}(\mathrm{WWW} 2)$

$\mathrm{P}(3 \mathrm{~W})$

$=$

$\mathrm{P}(\mathrm{WW} 1) \times \mathrm{P}(\mathrm{WWW} 2) \times \mathrm{P}(\mathrm{WWW} 3) \ldots($ Eq. 10)

Where,
$\mathrm{P}(2 \mathrm{D})=$ probability of 2 consecutive dry weeks starting with the week

P $($ DW1 $)=$ probability of the first week being dry

$\mathrm{P}(\mathrm{DDW})=$ probability of the second week being dry, given the preceding week being dry

$\mathrm{P}(3 \mathrm{D})=$ probability of 3 consecutive dry weeks starting with the week

$\mathrm{P}(\mathrm{DDW} 3)=$ probability of the third week being dry, given the preceding week dry

$\mathrm{P}(2 \mathrm{~W})=$ probability of 2 consecutive dry weeks starting with the week

$\mathrm{P}(\mathrm{WW} 1)=$ probability of the first week being wet

$\mathrm{P}(\mathrm{WWW})=$ probability of the second week being wet, given the preceding week being wet

$\mathrm{P}(3 \mathrm{~W})=$ probability of 3 consecutive wet weeks starting with the week

$\mathrm{P}(\mathrm{WWW})=$ probability of the third week being wet, given the preceding week wet.

\section{Analysis of air temperature}

\section{Normal temperature}

Seasonal, monthly, weekly normal temperatures $\left(\mathrm{T}_{\max }\right.$ and $\left.\mathrm{T}_{\min }\right)$ were calculated by using the software "Weather Cock" (WC).The input data file comprised of daily $\mathrm{T}_{\max }$ and $\mathrm{T}_{\min }$ over the period of given years which were taken from NASA power software. The module of WC named as "Normal.exe" was used to derive seasonal and monthly normal temperature and the annual temperature was derived by computing the total monthly normal temperature.

\section{Soil characterization}

Soil land type and soil texture plays a vital role in deciding the type and variety of crop to be grown in that area. Textural analysis is done for determine the percentage of sand, slit and clay by Bouyoucos hydrometer and the 
soil type were decided by using the textural triangle which needed for determining the available water holding capacity (AWHC).

\section{Length of growing period (LGP) assessment}

$\mathrm{LGP}=[$ Duration of rainy season in days + Post monsoon and winter rainfall $(\mathrm{mm})+$ AWHC $(\mathrm{mm} / \mathrm{m})$ /average evaporative demand of the atmosphere per day from agricultural field in post-monsoon and winter season](Sattar et al., 2013).

Average evaporative demand of the atmosphere in post monsoon and winter period from agricultural field in Dhenkanal was taken as $3.8 \mathrm{~mm}$ per day. As per soil characteristics, the available water holding capacity (AWHC) per one meter depth for Dhenkanalsadar and Kamakhyanagar soils was $150 \mathrm{~mm} / \mathrm{m}$. The AWHC of Bhuban, Gondia, Hindol, Kankadahad, Odapada and Parajang soils were taken as $100 \mathrm{~mm} / \mathrm{m}$.

\section{Determination of sowing window}

Sowing window of kharif paddy was determined basing on the onset and probability of rainfall, weekly rainfall $\mathrm{CV}$, the soil land and texture type after that from the LGP and duration of ruling rice variety of different blocks the pulse sowing window is adjusted.

Thresholds of rainfall for deciding sowing window of kharif paddy and rabi pulses using initial and conditional probabilities

For the district Dhenkanal to decide the sowing window of kharif paddy in the threshold limit of $20 \mathrm{~mm}$ per week, the land preparation was taken when the initial probability $(\mathrm{Pw})$ of rainfall in the pre monsoon shower is $>30 \%$ and the average weekly rainfall is $20-40 \mathrm{~mm}$. The sowing operation is done when the conditional probability of wet followed by wet week (Pww) is more than $50 \%$.The average weekly threshold limit of $\mathrm{CV}$ in the rainy season should be less than $150 \%$ which means there is high dependability of rainfall in the rainy season. During rabi period chances of occurrence of wet weeks are more than $30 \%$ and consecutive wet weeks are preferable for sowing of rabi pulses like green gram and black gram. The weekly CV of rainfall during the sowing period of rabi crop varies from 83 to $175 \%$. During this crop season the $\mathrm{CV}$ is more than threshold limit of $50 \%$. This indicates less dependability of rainfall during this period.

For the purpose of sowing, we have applied Markov Chain model by choosing 10 and 20 $\mathrm{mm}$ per week as threshold limits. These threshold levels were considered as adequate for the crop activities such as land preparation (10 mm), crop planting or sowing $(20 \mathrm{~mm})$. According to Reddy (2008), if a given week ' $i$ ' of a given year received more than 20 $\mathrm{mm} /$ week at more than $50 \%$ (W/W) threshold level, then week ' $i$ ' is the right time for planting.

The threshold levels for CV for any interpretation are $<25,<50,<100$ and $<$ $150 \%$ for annual, seasonal, monthly and weekly rainfall, respectively. If the $\mathrm{CV}$ is within the threshold limit of variability, it is considered that the rainfall is highly dependable and vice-versa (Manorama et al., 2007).

\section{Results and Discussion}

\section{Climatic characterization}

Mean annual rainfall for Dhenkanal district was $1367 \mathrm{~mm}$ while average number of rainy days were 64. Variability of annual rainfall among the all blocks of Dhenkanal district 
varied from 18 to $25 \%$ except Gondia block while $\mathrm{CV}$ of annual rainy days varied from 12 to $17 \%$ except Kankadahad (Pasupalak, 2015).Mean seasonal rainfall $(1055 \mathrm{~mm})$ and rainy days (50 days) were the highest in SW monsoon followed by post-monsoon. As a whole Dhenkanal received $77 \%$ of the mean annual rainfall during SW monsoon, which indicates all the blocks received sufficient amount of rainfall for kharif paddy except Parajang (Fig. 2) and 8\% during postmonsoon period which creates a better climatic condition of pulse production with the residual soil moisture after the harvest of kharif paddy in the fallow land but the postmonsoon rainfall was scanty for Kankadahada and Parajang (Fig. 3). So pulses can be cultivated in rice fallow land with the better utilisation of moisture or with assured irrigation.

Probability of occurrence of two to three consecutive dry weeks was $>90 \%$ from week 1 to 15 and also from week 45 to 52 standard meteorological week (SMW) at rainfall limit of $20 \mathrm{~mm}$, so sowing of rabi pulses should be done before 45 SMW. Probability of occurrence of two consecutive wet weeks was $>50 \%$ from week 25 to 37 . The range of probability of wet week in these weeks varied from 50 to $70 \%$, so kharif rice transplanting was done from 26 SMW (Chand et al., 2011).

The mean weekly minimum temperature at the sowing time i.e. from 40-44 SMW was $20-24^{\circ} \mathrm{C}$ (Table 1), which was optimum for sowing activity of pulses like green gram and black gram (Umata, 2018).

The post-monsoon mean maximum and minimum temperature were $27.8^{\circ} \mathrm{Cand}$ $18.9^{\circ} \mathrm{C}$ (Fig. 4), which was optimum for pulse cultivation in the rice fallow area. The onset of monsoon was in between 14-18 June (Table 2) and the cessation of monsoon was in between 8-13 October in the district.The rainy day was calculated as the day from onset of monsoon to cessation of monsoon. It was 115-120 days for most of the blocks (Table 2). It was the maximum (122 days) in Hindol block and the minimum (113days) in Odapada block. Most of the blocks had 106$133 \mathrm{~mm}$ post-monsoon and winter rainfall. Parajang had the minimum $(99 \mathrm{~mm})$ and Hindol had the maximum $(165 \mathrm{~mm})$ postmonsoon and winter rainfall (Table 3). The post-monsoon mean maximum temperature and minimum temperature was 27.8 and 18.9 (Fig. 4), respectively, which was optimum for the cultivation of rabi pulses in the rice fallow condition.

\section{Soil characterization}

Raychaudhuri et al., (1963) observed that, the soils most suited to rice cultivation are heavy soils and clays or clay loams. Such soils, with high water- holding capacity, produce higher rice yields and are suitable for second crop of pulses. Most of the blocks had medium land condition except Dhenkanal sadar and Kankadahad, where low land condition was high. Relay cropping is done particularly in rainfed low lands where excess moisture at the time of rice harvest does not permit tillage operation. However, sequential cropping after harvesting of rice and land preparation is practiced in medium lands (Kushwana and Ali, 1992) (Table 4).

\section{Length of growing period (LGP)}

The growing season begins with the onset of monsoon and end of the season happens in between 3-24 December (Table 5) in all blocks except Parajang where there is early withdrawal of soil moisture by 30 November. The duration of growing season for most of the block was 25 weeks (Table5) in soils having water holding $100 \mathrm{~mm} / \mathrm{m}$ capacity (Table 4) except Hindol and Parajang where it was 27 and 24 weeks, respectively. 
Table.1 Mean weekly maximum and minimum temperature $\left({ }^{\circ} \mathrm{C}\right)$ in post- monsoon season

\begin{tabular}{|c|c|c|c|}
\hline SMW & Tmax & Tmin & Optimum Temperature \\
\hline $\mathbf{4 0}$ & 29.8 & 23.9 & $\mathbf{2 6 . 8 5}$ \\
\hline $\mathbf{4 1}$ & 29.7 & 23.4 & $\mathbf{2 6 . 5 5}$ \\
\hline $\mathbf{4 2}$ & 29.3 & 22.7 & $\mathbf{2 6}$ \\
\hline $\mathbf{4 3}$ & 28.6 & 21.4 & $\mathbf{2 5}$ \\
\hline $\mathbf{4 4}$ & 28.2 & 20.4 & $\mathbf{2 4 . 3}$ \\
\hline $\mathbf{4 5}$ & 28.2 & 19.5 & $\mathbf{2 3 . 8 5}$ \\
\hline $\mathbf{4 6}$ & 27.7 & 18.5 & $\mathbf{2 3 . 1}$ \\
\hline $\mathbf{4 7}$ & 27.9 & 17.9 & $\mathbf{2 2 . 9}$ \\
\hline $\mathbf{4 8}$ & 27.4 & 16.9 & $\mathbf{2 2 . 1 5}$ \\
\hline $\mathbf{4 9}$ & 26.9 & 16.1 & $\mathbf{2 1 . 5}$ \\
\hline $\mathbf{5 0}$ & 26.9 & 16.3 & $\mathbf{2 1 . 6}$ \\
\hline $\mathbf{5 1}$ & 25.9 & 15.0 & $\mathbf{2 0 . 4 5}$ \\
\hline $\mathbf{5 2}$ & 25.6 & 14.4 & $\mathbf{2 0}$ \\
\hline District mean & $\mathbf{2 7 . 8}$ & $\mathbf{1 8 . 9}$ & $\mathbf{2 3 . 3 5}$ \\
\hline
\end{tabular}

Table.2 Block-wise onset, cessation of monsoon and monsoon rainy days

\begin{tabular}{|c|c|c|c|}
\hline Blocks & Onset of monsoon & Cessation of monsoon & $\begin{array}{l}\text { Monsoon } \\
\text { rainy days }\end{array}$ \\
\hline Bhuban & 17-Jun & 9-Oct & 115 \\
\hline Dhenkanal sadar & 17-Jun & $11-\mathrm{Oct}$ & 117 \\
\hline Gondia & 15-Jun & $10-$ Oct & 118 \\
\hline Hindol & 14-Jun & 13-Oct & 122 \\
\hline Kamakhyanagar & 17-Jun & 10-Oct & 116 \\
\hline Kankadahad & 14-Jun & $10-$ Oct & 119 \\
\hline Odapada & 18-Jun & 8-Oct & 113 \\
\hline Parjang & 18-Jun & 10-Oct & 115 \\
\hline
\end{tabular}

Table.3 Block-wise post-monsoon and winter rainfall

\begin{tabular}{|c|c|}
\hline Blocks & $\begin{array}{c}\text { Post-monsoon and winter rainfall } \\
(\mathbf{m m})\end{array}$ \\
\hline Bhuban & 123 \\
\hline Dhenkanal sadar & 133 \\
\hline Gondia & 118 \\
\hline Hindol & 165 \\
\hline Kamakhyanagar & 109 \\
\hline Kankadahad & 106 \\
\hline Odapada & 118 \\
\hline Parjang & 99 \\
\hline District mean & 121 \\
\hline
\end{tabular}


Table.4 Block wise average evaporation demand ( $\mathrm{mm} /$ day) and available water holding capacity of soil in post-monsoon and winter season

\begin{tabular}{|c|c|c|}
\hline Blocks & AWHC $(\mathbf{m m} / \mathbf{m})$ & $\begin{array}{c}\text { Average } \\
\text { EVP(mm/day) }\end{array}$ \\
\hline Bhuban & 100 & $\mathbf{3 . 8}$ \\
\hline Dhenkanal sadar & 150 & $\mathbf{3 . 8}$ \\
\hline Gondia & 100 & $\mathbf{3 . 8}$ \\
\hline Hindol & 100 & $\mathbf{3 . 8}$ \\
\hline Kamakhyanagar & 150 & $\mathbf{3 . 8}$ \\
\hline Kankadahad & 100 & $\mathbf{3 . 8}$ \\
\hline Odapada & 100 & $\mathbf{3 . 8}$ \\
\hline Parjang & $\mathbf{1 0 0}$ & $\mathbf{3 . 8}$ \\
\hline
\end{tabular}

Table.5 Block wise duration of growing season (LGP)

\begin{tabular}{|l|c|c|c|c|}
\hline Blocks & $\begin{array}{c}\text { Start of growing } \\
\text { season }\end{array}$ & $\begin{array}{c}\text { End of growing } \\
\text { season }\end{array}$ & LGP(days) & LGP(weekly) \\
\hline Bhuban & 17 June & 7 Dec & 174 & $\mathbf{2 5}$ \\
\hline Dhenkanal sadar & 17 June & 24 Dec & 191 & $\mathbf{2 7}$ \\
\hline Gondia & 15 June & 9 Dec & 178 & $\mathbf{2 5}$ \\
\hline Hindol & 14 June & 22 Dec & 192 & $\mathbf{2 7}$ \\
\hline Kamakhyanagar & 17 June & 17 Dec & 184 & $\mathbf{2 6}$ \\
\hline Kankadahad & 14 June & 3 Dec & 173 & $\mathbf{2 5}$ \\
\hline Odapada & 18June & 6 Dec & 172 & $\mathbf{2 5}$ \\
\hline Parjang & 18 June & 30 Nov & 167 & $\mathbf{2 4}$ \\
\hline District mean & & & $\mathbf{1 7 9}$ & $\mathbf{2 6}$ \\
\hline
\end{tabular}

Table.6 Block-wise sowing window of kharif rice in Dhenkanal

\begin{tabular}{|l|c|c|}
\hline \multicolumn{1}{|c|}{ Blocks } & SMW & Month \\
\hline Bhuban & 23 & 4-10 June \\
\hline Dhenkanal sadar & 23 & 4-10 June \\
\hline Gondia & 24 & 11-17 June \\
\hline Hindol & 23 & 4-10 June \\
\hline Kamakhyanagar & 23 & 4-10 June \\
\hline Kankadahad & 22 & $\mathbf{2 8}$ May-3 June \\
\hline Odapada & 24 & $\mathbf{1 1 - 1 7}$ June \\
\hline Parjang & $\mathbf{2 4}$ & $\mathbf{1 1 - 1 7 J u n e}$ \\
\hline
\end{tabular}


Table.7 Block-wise sowing window of rabi pulses in Dhenkanal

\begin{tabular}{|c|c|c|c|c|}
\hline \multirow[t]{3}{*}{ Blocks } & \multicolumn{4}{|c|}{ Sowing window of pulses } \\
\hline & \multicolumn{2}{|c|}{ Medium land } & \multicolumn{2}{|c|}{ Low land } \\
\hline & SMW & Month & SMW & Month \\
\hline Bhuban & 41 & 8-14 Oct & 41-42 (Paira) & 11-17 Oct (paira) \\
\hline $\begin{array}{l}\text { Dhenkanal } \\
\text { sadar }\end{array}$ & 41 & $8-14$ Oct & $\begin{array}{l}\text { 44- } 45 \text { (zero till } \\
\text { method)/ } 41-42 \\
(\text { Paira })\end{array}$ & $\begin{array}{l}\text { 1-7Nov (zero till)/ } \\
\text { 11-17 Oct (paira) }\end{array}$ \\
\hline Gondia & 42 & $15-210 c t$ & 42-43 (Paira) & 18-24 Oct (Paira) \\
\hline Hindol & 41 & $8-140 c t$ & $44-45$ (zero till) & 1-7 Nov (Nov) \\
\hline Kamakhyanagar & 41 & 8-14 Oct & 41-42 (Paira) & 11-17 Oct (Paira) \\
\hline Kankadahad & 40 & $1-7$ Oct & 40-41 (Paira) & 4-10 Oct (Paira) \\
\hline Odapada & 42 & $15-21$ Oct & 42-43 (Paira) & 18-24 Oct (Paira) \\
\hline Parjang & 41 & 8-14 Oct & 42-43 (Paira) & 18-24 Oct (Paira) \\
\hline
\end{tabular}

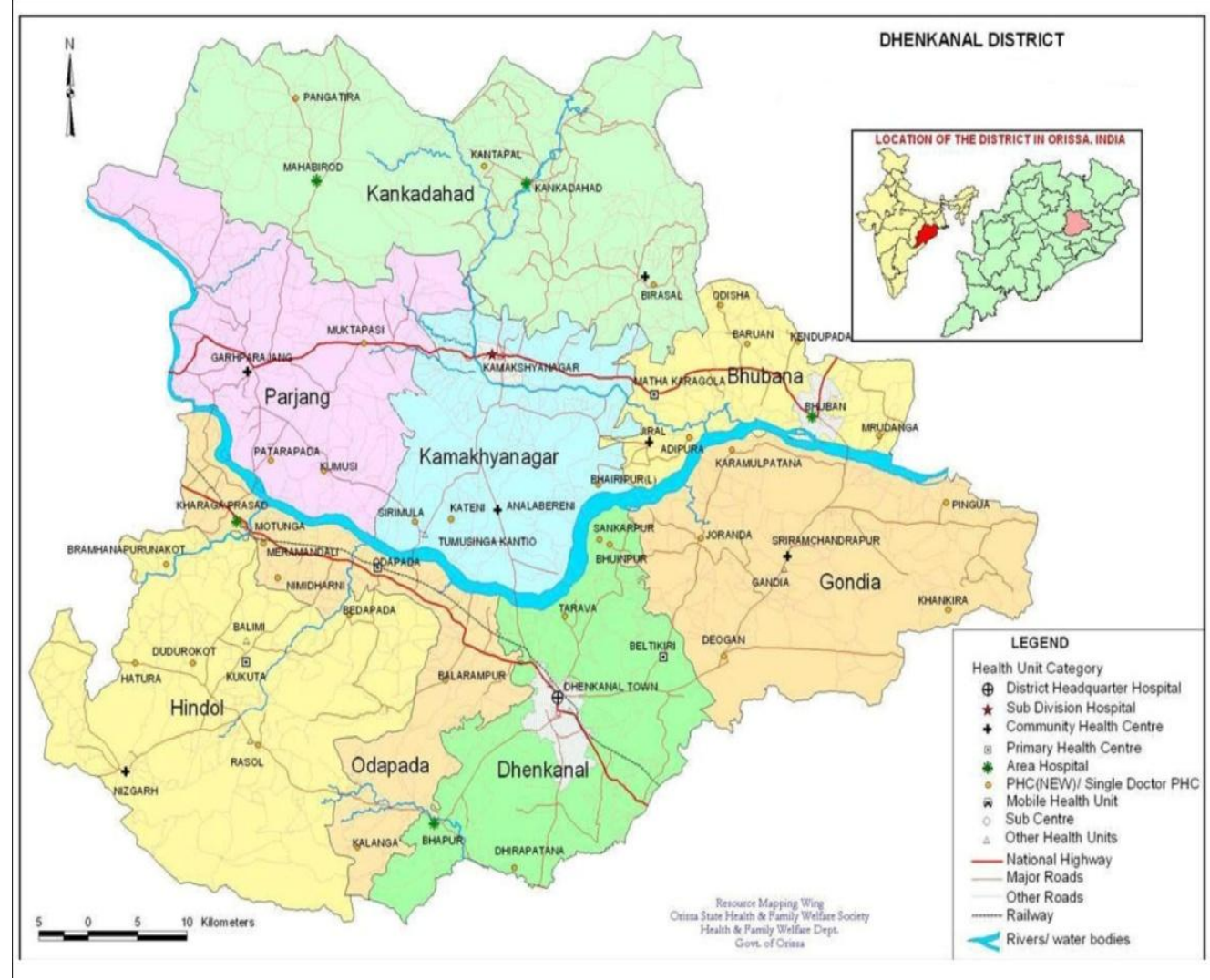

Fig.1 District map of Dhenkanal 


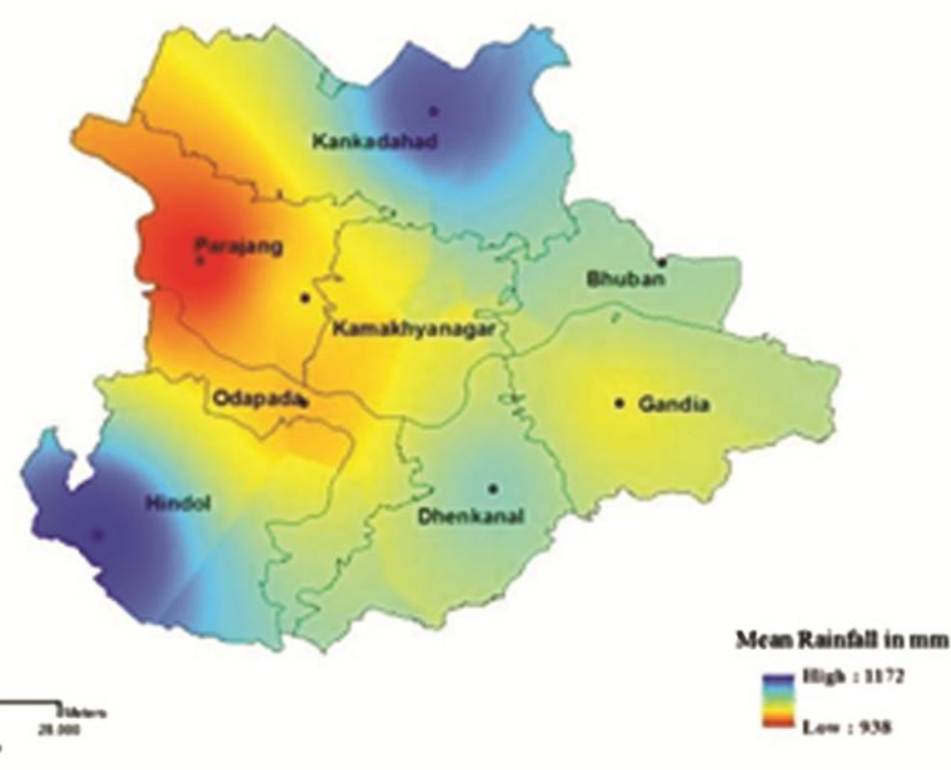

Fig.2 Block-wise mean South-west monsoon rainfall

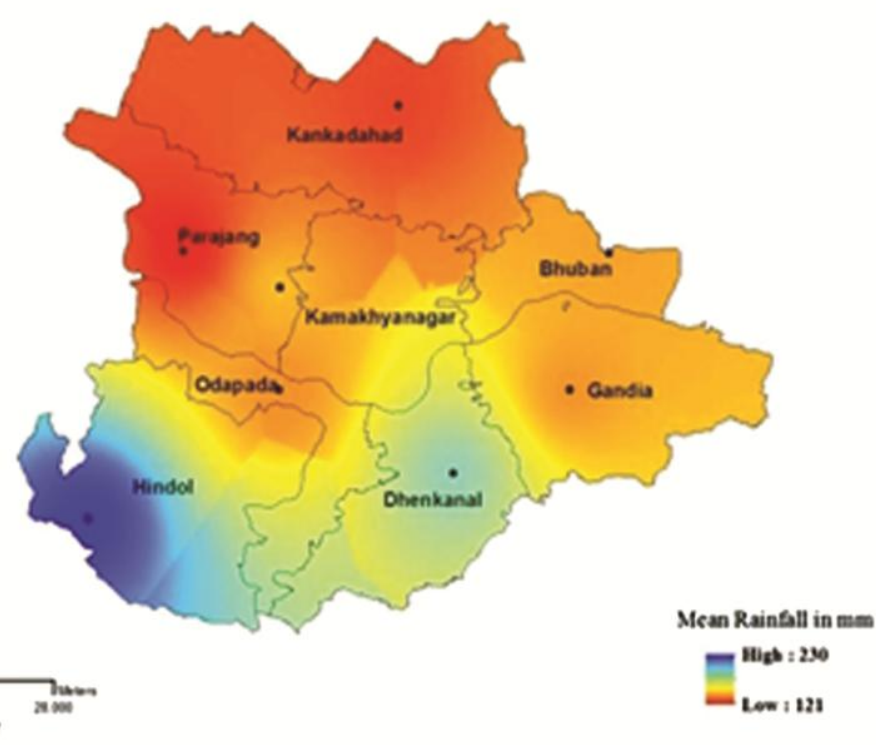

Fig.3 Block-wise mean post- monsoon rainfall 


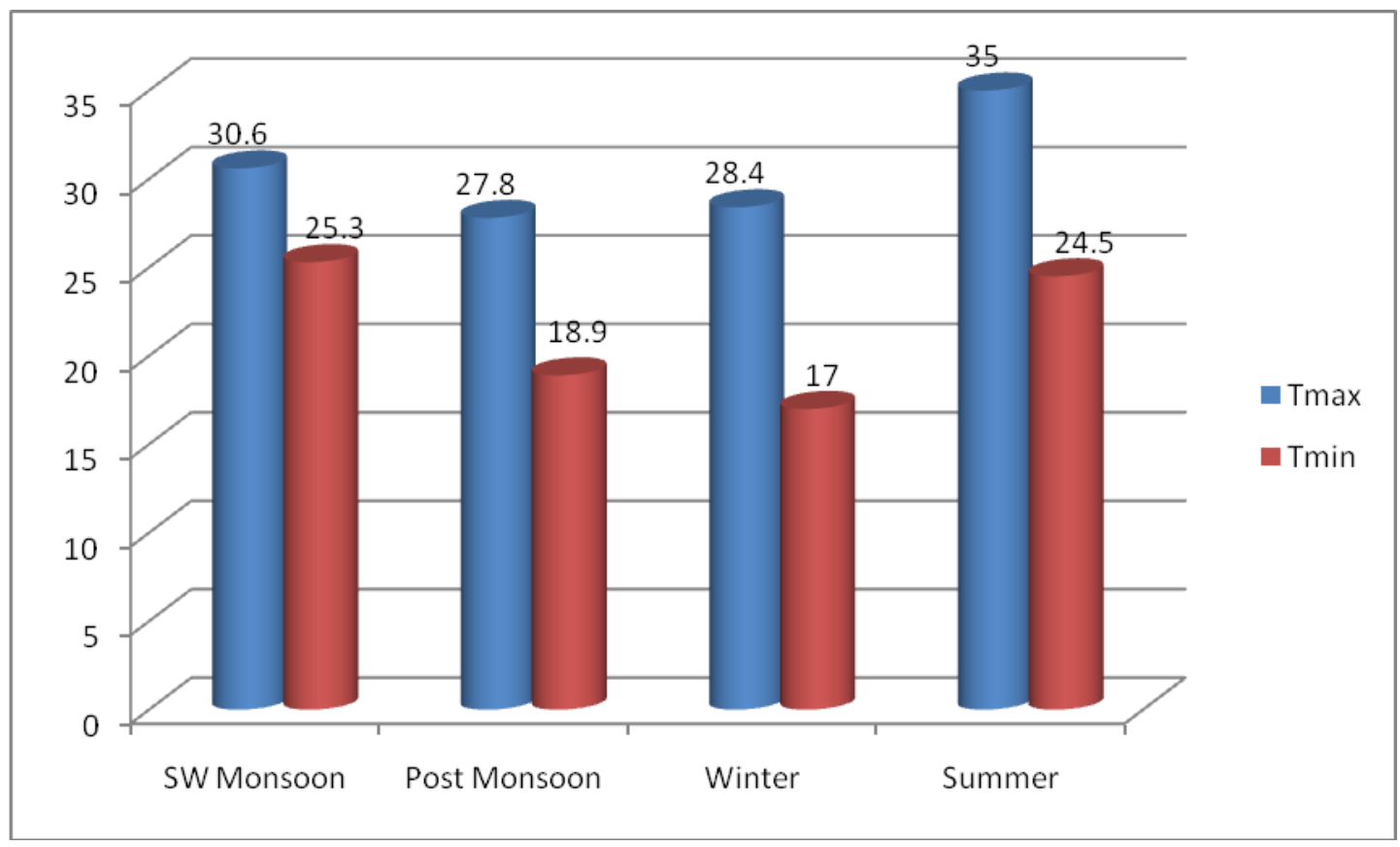

Fig.4 Mean Seasonal temperature

\section{Sowing window of rice}

The land preparation is usually done in 21-22 SMW for most of the blocks when the initial probability was $>30 \%$. The sowing window of kharif rice in Dhenkanal district was found in between 23-24 SMW (Table 6) except Kankadahad, when the conditional probabilities of wet followed by wet $\left(\mathrm{P}_{\mathrm{ww}}\right)$ was $>50 \%$ for $20 \mathrm{~mm}$ threshold limit (Mandal et al., 2015).

Mid duration (120days) variety like 'Naveen', 'Lalat', 'Konark' and mid late (145days) duration rice variety like 'Swarna', 'Pratikhya', 'Rani dhan' are harvested between 40-41SMW in medium land and 4245 SMW in low land respectively.

Mid duration rice are preferred for rice fallow pulse cultivation because it was harvested within 15 October in all blocks then there was vast scope for utilizing the residual soil moisture in the growing season, but in case of long duration rice variety cultivation we should go for paira before 10-15 days of harvest of rice (Mazid et al., 1997).

\section{Sowing window of pulses}

The sowing window of rabi pulses are determined according to the LGP, duration of kharif rice and when both the initial and conditional probabilities are $>30 \%$ (Ray et al., 2018). In medium land condition, sowing window is in 40 SMW in Kanakadahad, 41 SMW in Bhuban, Dhenkanal sadar, Hindol, Kamakhyanagar and Parajang and 42 SMW in Odapada, respectively (Table 7) by zero till method after the harvest of mid duration kharif rice (Chand et al., 2011).

In low land condition of Dhenkanal, rabi pulses can be sown in between 44-45 SMW in Dhenkanal sadar and in Hindol by zero till method, after mid late duration rice harvest. In between 40-41 SMW in Kanakadahad, 4142 SMW in Bhuban, Dhenkanal sadar and Kamakhyanagar, 42-43 SMW (Table 7) in Gondia, Odapada and Parajang green gram variety like 'IPM-02-03', 'PDM-54'and black gram variety like 'PU-31'are sown with the residual soil moisture by paira method i.e. 1520 days before the harvest of mid late duration rice. 
The average weekly rainfall variability was $120-170 \%$ and average weekly minimum temperature was $20-23^{\circ} \mathrm{C}$ in all blocks, which is optimum for seeding and germination of pulses in that sowing week. Mid and mid late duration rice which are sown at 23-24 SMW [when the conditional probabilities of wet followed by wet week is (Pww) $>50 \%$ ], and harvested in between 40-41SMW in medium land and 42-45 SMW in low land, respectively. This study reveals that there is 115- 120 monsoon rainy days, so the farmers can go for short to mid duration kharif rice variety for better utilization of residual soil moisture in the fallow land by cultivating short duration (65-70days) rabi pulses.

The LGP is 170-180 days for most of the blocks and above 180 days for Dhenkanal sadar, Hindol and Kamakahyanagar. There is maximum scope for utilization of residual soil moisture in those blocks by sowing of pulses in rice-fallow area during 41-42 SMW in medium land by zero till method and 41-43 SMW in low land by paira method. However, suitable strategies for adjustment in sowing window of both kharif rice and rabi pulse crops could be a boon for enhancing the system productivity and profitability of the farming community under challenging ricefallow condition.

\section{References}

Ati,O.F., Stigter, C.J. and Oladipo, E.O. (2002). A comparison of methods to determine the onset of growing season in Northern Nigeria. J. Climatol., 22: 731-742.

Bussmann, A., Elagib, N.A., Fayyad, M. and Ribbe, L. (2016). Sowing date determinants for Sahelian rainfed agriculture in the context of agricultural policies and water management. Land Use Policy, 52:316-328.

Chand, M., Kumar, D., Singh, D., Roy, N. and Singh, D.K. (2011). Analysis of rainfall for crop planning in Jhansi district of Bundelkhand zone of Uttar Pradesh. Indian J. Soil Conserv.,39(1): 20-26.

Dash, M.K. and Senapati, P.C. (1992). Forecasting of dry and wet spell at Bhubaneswar for agricultural planning. Indian J. Soil Conserv.,20(1\&2):75-82.

Joseph, A. and Tamilmani, D. Markov chain model of weekly rainfall probability and dry and wet spell for agricultural planning in Coimbatore in western zone of Tamil Nadu. Indian J. Soil Conserv. 45: 66-71

Kar, G., Singh, R. and Verma, H.N. (2004). "Productive and profitable management of rainfed lowland rice through intensive cropping and efficient water use". WTCER Research Bulletin Number 17/2004, Water Technology Centre for Eastern Region, Bhubaneswar.

Kushwana, B.L. and Ali, M. (1992). Nutrient management of pulses in rice-fallows of eastern India. In: "Compilation of talks, summer institute on management of pulses in cropping system". 19 May - 7 June 1992, pp. 7, 83. (Directorate of Pulses Research, Kanpur).

Mandal, K.G., Padhi, J., Kumar, A., Ghosh, S., Panda, D.K., Mohanty, R.K. and Raychaudhuri, M. (2015). Analyses of rainfall using probability distribution and Markov chain models for crop planning in Daspalla region in Odisha, India. Theor. Appl.Climatol.121:517528.

Manorama, K., Ravichandran, G. And Joseph, T.A. (2007). Rainfall analysis and crop planning for the Nilgiris. J. Agrometeorol., 9: 209-215.

Mazid, M.A., Mannan, M.A., Mollah, M.L.U., Ahmed, H.U., Haran, M. and Ali, A. (1997). Technology packages for rice-based cropping system for 
increased productivity of Rajshahi region. In: "Proceedings of the Farmer Extension Workshops in collaboration with DAE, BRR and BAR during October 1996 to August 1997. Dhaka, Bangladesh". Pp. 92-104. Thana Cereal Technology Project and Identification Project (GOB/UNDP/FAP/Project $\mathrm{BGD} / 89 / 045)$.

Pandarinath, N. (1991). Markov chain model probability of dry and wet weeks during monsoon periods over Andhra Pradesh. Mausam, 42(4):393-400

Pasupalak, S. (2015). "Agroclimatic Atlas of Odisha". All India Coordinated Research Project on Agrometeorology, Orissa University of Agriculture and Technology, Bhubaneswar.

Praharaj, C. S. and Ummed Singh (2018).Scaling soil fertility and productivity of pulses under rice fallows in Eastern India. In: "Farm Mechanization for Production" (Eds. D. Khare, S.B. Nahatkar, A.K. Shrivastava and A.K. Jha). pp. 220 (Scientific Publishers).

Ray, M., Biswal, S., Sahoo, K.C. and Patra, H. (2018). A Markov chain approach for wet and dry spell and probability analysis. Int.J.Curr.Microbiol.App.Sci., Special Issue 6: 1005-1013.

Raychaudhutri, S.P., Agarwal, R.R., DattaBiswas, N.R., Gupta, S.P. and Thomas, P.K. (1963). Soils of India. New Delhi, India (Indian Council of Agricultural Research).

Reddy, G.V.S., Bhaskar, S.R., Purohit, R.C. and Chittora, A.K. (2008). Markov chain model probability of dry, wet weeks and statistical analysis of weekly rainfall for agricultural planning at Bangalore. Karnataka J. Agric. Sci., 21(1): 412-418.

Sattar, A., Kumar, M., Bobade, P. and Chandrawanshi, S. (2013). Assessing the length of growing season and drought incidence in Bihar. $J$. Agrometeorol., 15(Special Issue-I):1-3.

Singh, N.P., Praharaj, C.S. and Sandh, U.J.S. (2016). Utilizing untapped potential of rice fallow of East and North-east-India through pulse production, ICAR-Indian Institute of Pulses Research, Kanpur, Uttar Pradesh

Umata, H. (2018). Evaluation of adaptability of mung bean varieties in moisture stress of Eastern Harerghe Zone. Agric.Res.Technol., 13(2): 555880.

\section{How to cite this article:}

Jena, D., A. K. B. Mohapatra, B. S. Rath and Baliarsingh, A. 2020. Assessment of Sowing Window of Rice-Pulse Cropping System According to the Length of Growing Period and Different Climatic Parameter Analysis in Dhenkanal District of Odisha, India. Int.J.Curr.Microbiol.App.Sci. 9(05): 1819-1830. doi: https://doi.org/10.20546/ijcmas.2020.905.207 